Discussion Paper No. 02-22

How Integrated are the European Retail Financial Markets? A Cointegration Analysis

Martin Schüler and Friedrich Heinemann

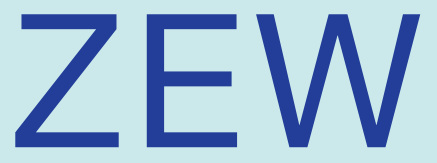

Zentrum für Europäische Wirtschaftsforschung GmbH

Centre for European Economic Research 
Discussion Paper No. 02-22

\title{
How Integrated are the European Retail Financial Markets? A Cointegration Analysis
}

\author{
Martin Schüler and Friedrich Heinemann
}

Download this ZEW Discussion Paper from our ftp server:

ftp://ftp.zew.de/pub/zew-docs/dp/dp0222.pdf

Die Discussion Papers dienen einer möglichst schnellen Verbreitung von neueren Forschungsarbeiten des ZEW. Die Beiträge liegen in alleiniger Verantwortung der Autoren und stellen nicht notwendigerweise die Meinung des ZEW dar.

Discussion Papers are intended to make results of ZEW research promptly available to other economists in order to encourage discussion and suggestions for revisions. The authors are solely responsible for the contents which do not necessarily represent the opinion of the ZEW. 


\section{Non-Technical Summary}

There is a wide literature that tries to measure integration in financial markets. The results of these studies differ substantially. The predominant part of it is concerned with wholesale financial markets such as the money market and the bond market. They find evidence that these markets are integrated to a high degree. Customers in these markets are able to choose offers from different locations quit easily. With the introduction of a single European currency a single European money market emerged, too. However, in retail financial markets the physical distance to a certain bank still determines to a large extent the preference of the customer. Thus, integration in retail financial markets is lacking behind integration in wholesale markets. So far only a few studies have analysed the degree of integration in the European retail financial market. Our study contributes to this discussion. We analyse four lending markets and two deposit markets by testing for bivariate and multivariate cointegration between national interest rate spreads. Namely we examine mortgage loans to households, consumer loans to households, short-term loans to enterprises, medium and long-term loans to enterprises, time deposits, and savings accounts. The study is conducted for Austria, Belgium, Finland, France, Germany, Ireland, Italy, the Netherlands, Portugal, Spain and the United Kingdom, although not all retail rates are available for every country.

European retail financial markets are characterised by heterogeneity across countries that is caused by, for example, risk differences, cultural influences in bank-client relationship, country-specific strategic bank behaviour in order to cope with informational imperfections such as moral hazard or incentive effects. Consequently, prices will not strictly equalise even in fully integrated markets. The law of one price can hold solely for assets that are perfect substitutes across countries. However, pricing in retail banking will be more closely tied together within an increasingly integrating region. Thus, in integrated markets there should exist a certain long-run relationship between interest rates across countries. Cointegration means that there exists such a long-run relationship between two or more time series. Thus, the existence of cointegration is taken as an indicator for financial market integration.

There are differences across the different markets. We found little cointegration in the market for mortgage loans to households. So far there exists no single European mortgage loans market although there is some evidence for integration in Belgium, Germany, the Netherlands and maybe Spain. The market for consumer loans does not show any sign of integration. The slightly higher degree of integration for mortgages may be explained by the fact that in the mortgage market, for example, monitoring is a smaller problem than in the consumer loans market where also personal bank-customer-relationships probably play a major role. 
More integrated seems to be the European market for short-term loans to enterprises. We get also evidence that the market for medium and long-term loans to enterprises is to some extent integrated since we found in almost every second case cointegration. In general, enterprises may borrow money from a bank abroad rather than consumers. Thus, cross-border competition in the markets for loans to enterprises probably is higher than in the markets for mortgage or consumer loans. This puts more pressure on banks in the enterprise loans market to pass a decrease in their cost of funds, i.e. the money market rate to the lenders. In this way financial market integration is fostered and this explains our findings of lower integration in the mortgage and consumer loans market than in the loans markets for enterprises.

For the time deposits market we found some evidence that this market is integrated to a large extent. This seems to be plausible since traditionally time deposits are strongly linked to the money market. With the introduction of a single currency a single European money market emerged which in the case of time deposits may have enforced integration. In addition, compared to savings deposits were we found little evidence for integration time deposits are predominantly made by wealthier or even institutional investors that may rather invest in a foreign country than a "normal saver". Thus, also higher cross-border competition may foster market integration. A possible explanation for the lack of integration in the savings deposit market may be that savings deposits are usually made by savers that attach much importance to a personal customer-bank-relationship. Hence, cross-border competition is probably relatively low hindering integration in this market. 


\title{
How integrated are the European Retail Financial Markets? A Cointegration Analysis
}

\author{
Martin Schüler and Friedrich Heinemann \\ Centre for European Economic Research (ZEW), Mannheim, Germany*
}

January 2002

\begin{abstract}
With the introduction of the Euro, a single European money market has emerged. Further wholesale financial markets are considered to be highly integrated within the European Union. However, integration in retail financial markets is less advanced. For measuring financial market integration this distinction between wholesale and retail markets becomes crucial. There is a wide literature relating to integration of wholesale financial markets but just a few studies that try to measure integration in European retail markets. This paper, in a first step, gives a systematisation of the literature on measuring financial market integration with a focus on the distinction between wholesale and retail financial markets. In a second step, bivariate and multivariate cointegration techniques are used to assess the degree of integration in four loans and two deposit markets in the European Union. Finally, based on this analysis obstacles to financial market integration are discussed.
\end{abstract}

JEL-Classification: F36, G15

Keywords: Financial Market Integration, Cointegration, European Union

* P.O. Box 103443, D-68034 Mannheim, Germany, Phone: +49/621/1235-148 (-149),Fax:+49/621/1235-223, E-mail: schueler@zew.de,heinemann@zew.de.

Acknowledgement: The authors gratefully acknowledge financial support from the Financial Services European Roundtable, Brussels. They also thank Michael Schröder, Herbert Buscher (both ZEW, Mannheim) and Jürgen Weigand (WHU, Vallendar) for helpful comments. 


\section{Motivation}

There is a wide literature that tries to measure integration in financial markets. The results of these studies differ substantially. The predominant part of it is concerned with wholesale financial markets. Clearly, in the context of measuring integration the distinction between wholesale capital markets and retail financial markets becomes crucial. It appears that often this dichotomy between wholesale and retail financial markets is not sufficiently taken into account when assessing the degree of financial market integration.

In general, the existing evidence suggests that the wholesale financial markets such as the money market and the bond market are integrated to a high degree. Customers in these markets are able to choose offers from different locations quit easily. With the introduction of a single European currency a single European money market emerged, too. However, in retail financial markets the physical distance to a certain bank still determines to a large extent the preference of the customer. Thus, integration in retail financial markets is lacking behind integration in wholesale markets.

In 1988, the Cecchini-Report (Commission of the European Communities, 1988) gave evidence of substantial fragmentation of the European financial services markets since it found substantial price differentials. In addition, potential benefits arising for the consumers with further integration were estimated. In order to realise some of these benefits the second banking directive was implemented in 1993 and formally a single European banking market was established.

So far only a few studies have analysed the degree of integration in the European retail financial market coming to the result that retail markets are still to a large amount fragmented. Our study contributes to this discussion by extending the study by Sander and Kleimeier (2001). We examine four loans markets and two deposit markets using bivariate and multivariate cointegration techniques.

The paper is organised as follows: Section 2 gives a systematisation of the existing literature for measuring financial market integration in general considering the distinction between wholesale and retail financial markets. In section 3, the degree of integration in six financial retail markets is assessed. Finally, based on the results of the cointegration analyses obstacles to integration in the market for financial services are discussed.

\section{Measuring financial market integration - a systematisation}

Perfect financial integration is given if national borders do not play any role for cross-border financial transactions. Since the extreme cases of perfect integration 
and no integration are only of theoretical interest, the aim of the following analysis is to assess the degree to which financial markets are integrated.

Financial market integration can be measured directly or indirectly. Direct approaches target at the identification of regulatory and economic barriers to international capital mobility ${ }^{l}$. Indirect approaches relate to the observable consequences of existing barriers and are either quantity or price related. ${ }^{2}$

Table 1 gives a systematisation of the different approaches to measure financial market integration with regard to the distinction between wholesale and retail financial markets. The contrasting results of existing studies emphasise the importance of this distinction.

\subsection{Quantity concepts}

The most widely known quantity measure involves looking at correlations between saving and investment proposed by Feldstein and Horioka (1980). ${ }^{3}$ This test is based on the following idea: In a world with fully integrated capital markets and a single world interest rate, domestic investment is independent of domestic saving since it can be financed by foreign saving. If capital is perfectly mobile a shortfall in domestic saving in one country should not increase the domestic real interest rate or crowd out investment, since borrowing from abroad at the world interest rate is possible. Therefore, low (high) correlations indicate high (low) international capital mobility.

${ }^{1}$ The Annual Report on Exchange Arrangements and Exchange Restrictions of the IMF lists barriers to international capital flows for all IMF member countries. Beside those official restrictions there are, of course, a lot of other barriers, such as differences in language and culture or information asymmetries. To know of such barriers is certainly important when talking about how integrated financial markets are. However, this information is not easily interpreted since the importance of specific barriers is not known (Goldstein and Mussa, 1993).

${ }^{2}$ Schulze and Ursprung (1999) differentiate in that way when measuring globalisation.

${ }^{3}$ For a good discussion of the Feldstein-Horioka-study see e.g. Heinemann and Stirböck (1999). 
Table 1: Measuring financial market integration

\begin{tabular}{|c|c|c|c|}
\hline \\
\hline & \multirow{2}{*}{\begin{tabular}{|l|} 
Direct approaches \\
$\begin{array}{c}\text { I Identification of regulatory and economic } \\
\text { barriers }\end{array}$ \\
\end{tabular}} & \multicolumn{2}{|l|}{ Indirect approaches } \\
\hline & & II Price measures & III Quantity measures \\
\hline $\begin{array}{l}\text { A } \\
\text { Integration of } \\
\text { financial markets } \\
\text { (focus on } \\
\text { wholesale } \\
\text { markets) }\end{array}$ & $\begin{array}{l}\text { Barriers relevant for transactions among } \\
\text { professional financial market actors, such as } \\
\text { existence of capital controls, regulatory } \\
\text { impediments, information costs, transaction costs } \\
\text { (IMF, The Annual Report on Exchange } \\
\text { Arrangements and Exchange Restrictions) }\end{array}$ & $\begin{array}{l}\text { Price equalisation for financial market assets (law } \\
\text { of one price) } \\
\text { - Interest rate parity conditions (Frankel, } \\
\text { McArthur, 1988, Frankel, 1993, Lemmen/ } \\
\text { Eijffinger, 1993, Eijffinger/Lemmen, 1995, } \\
\text { Lemmen/Eijffinger, 1995) } \\
\text { - Cointegration of interest rates (Centeno/ } \\
\text { Mello, 1999) } \\
\text { Stock Market Integration using } \\
\text { - Uncovered interest parity (Fratzschner, } \\
\text { 2001) } \\
\text { - Arbitrage pricing theory (Ferson/Harvey, } \\
\text { 1991, Bekaert/Harvey, 1995, Dumas/ } \\
\text { Solnik, 1995, Hardouvelis et al., 1999) } \\
\text { Distance between sets of stochastic } \\
\text { discount factors (Chen/Knez, 1995, } \\
\text { Ayuso/Blanco, 2000) }\end{array}$ & $\begin{array}{l}\text { Saving-Investment-Correlations } \\
\text { (Feldstein/Horioka, 1980, Feldstein, 1982, } \\
\text { Obstfeld, 1985, Summer, 1988, Sinn, 1992, } \\
\text { Taylor, 1994, 1996, Lemmen/Eijfinger, 1995) } \\
\text { Consumption-Correlations (Obstfeld, 1989, } \\
\text { 1994 1995, Mace, 1991, Lemmen/ Eijffinger, } \\
\text { 1995, Bayoumi/MacDonald, 1995, Olivei, } \\
\text { 2000) }\end{array}$ \\
\hline $\begin{array}{l}\text { B } \\
\text { Integration of } \\
\text { financial services } \\
\text { markets (focus on } \\
\text { retail markets) }\end{array}$ & $\begin{array}{l}\text { Barriers relevant for transactions between financial } \\
\text { enterprises and private consumers, such as } \\
\text { existence of capital controls, regulatory } \\
\text { impediments, information costs, transaction costs } \\
\text { (IMF, The Annual Report on Exchange } \\
\text { Arrangements and Exchange Restrictions) }\end{array}$ & $\begin{array}{l}\text { Price equalisation for financial services (law of one } \\
\text { price) } \\
\text { - } \quad \text { Cecchini-Report } \\
\text { - } \quad \text { Cointegration of interest rates (Centeno/ } \\
\text { Mello, 1999, Kleimeier/Sander, 2000, } \\
\text { Sander/Kleimeier, 2001) } \\
\text {-Antitrust-Literature" (Stigler/Sherwin, 1985, } \\
\text { Keeley/Zimmerman, 1985, Berger/ Hannan, } \\
\text { 1989, Hannan, 1991, Hannan/ Berger, 1991, } \\
\text { Neumark/Sharpe, 1992, Jackson, 1992, } \\
\text { Rhoades, 1992, Radecki, 1998, 1999, } \\
\text { Heitfield, 1999) }\end{array}$ & $\begin{array}{l}\text { - Micro Home Bias Literature" (Tesar/Werner, } \\
\text { 1992, Lewis, 1999, Hess/Shin, 2000) }\end{array}$ \\
\hline
\end{tabular}


Another quantity approach looks at correlations between consumption across countries (Obstfeld, 1989). ${ }^{4}$ When markets are fully integrated individuals are able to ensure themselves against unexpected changes in their income streams stemming from regional shocks by diversifying their portfolio holdings. A high correlation between domestic and foreign consumption indicates a high degree of cross-border capital mobility and a high degree of financial market integration. ${ }^{5}$

By looking at correlations between saving and investment or between consumption across countries studies usually find evidence for relatively low degrees of capital mobility and subsequently low financial market integration. However, there are a number of studies (Tobin, 1983, Murphy, 1984, Obstfeld, 1985, Summers, 1988, Bayoumi, 1990, Taylor, 1994) that point out several shortcomings of the Feldstein/Horioka-test arguing that this criterion measures more than financial capital mobility alone since high correlations between saving and investment do not necessarily contradict international capital mobility. ${ }^{6}$ Thus, quantity measures à la Feldstein-Horioka do not seem very promising in assessing the degree of financial market integration.

\subsection{Price measures}

The basic idea behind price measures is that in a perfectly integrated financial market arbitrage should safeguard that prices of identical assets traded in different markets are equal, i.e. the law of one price holds. Hence assessing the degree of financial market integration implies measuring the degree to which capital flows equalise expected returns on comparable assets traded in different countries and possibly denominated in different currencies (Eijffinger and Lemmen, 1995). According to Frankel $(1992,1993)$ and Lemmen and Eijffinger (1993) there are three different concepts of defining perfect capital mobility, that fit into the price approach. ${ }^{7}$ Those are well known as the interest parity conditions, namely covered nominal interest parity (CIP), ex ante uncovered interest parity (UIP), and ex ante real interest parity (RIP). ${ }^{8}$ Obviously, the introduction of a single European currency

${ }^{4}$ This approach also refers to the so called "risk-sharing" hypothesis.

${ }^{5}$ On the micro level there is numerous evidence that consumers within countries, i.e. within an area of high capital mobility, do not fully smooth out consumption. Consumers clearly prefer shares and bonds issued in the home country. This lack of interregional risk diversification is widely know as the so called home bias in investment portfolios (e.g. Tesar and Werner, 1992, Lewis, 1999, Hess and Shin, 2000).

${ }^{6}$ For a useful survey of the criticism of the Feldstein-Horioka criterion see for example Lemmen and Eijffinger (1995).

${ }^{7}$ A forth method of measuring capital mobility is the Feldstein-Horioka-criterion discussed above.

${ }^{8}$ For a description of the interest parity concepts see for example Frankel (1992, 1993), Lemmen and Eijffinger (1995). 
has removed the existence of an exchange risk premium within the European Union. As a result, tests for interest parity in order to assess the degree of financial market integration within EMU make no sense.

Usually, studies employing interest parity conditions focus on money market rates or other wholesale interest rates. Besides, there is a wide literature that tries to assess the degree of stock market integration. These studies use, for example, uncovered interest parity (e.g., Fratzschner, 2001) or some specification of the arbitrage pricing theory (APT) (e.g., Bekaert and Harvey, 1995, Dumas and Solnik, 1995, Ferson and Harvey, 1991, Hardouvelis et al., 1999).

\subsection{Measuring integration in retail financial markets}

Clearly, the above approaches aim on measuring integration in wholesale financial markets such as the money, the bond, or the stock market. Most of the studies considering wholesale financial prices lead to the conclusion that the degree of financial market integration is quite high. Obviously, since the introduction of a single currency on January 1, 1999, there is a single money market in the Euro zone and also the integration of other wholesale financial markets can be considered to be far advanced. However, the retail financial markets seem to remain quite fragmented in Europe and so far not much research work has been undertaken on this issue.

There are a number of studies that incorporate price data in order to measure integration in retail financial markets in the US. ${ }^{9}$ These studies were often motivated from an antitrust point of view as they tried to quantify the regional extension of the market for financial services. If banking markets are non-local - i.e. "integrated" in our terminology - then local supply and demand conditions would not be relevant in the evaluation of the competitive effects of any given local merger (Rhoades, 1992).

However, there are only a few studies that try to measure integration in the European retail financial markets. In 1988 the Cecchini-Report (Commission of the European Communities, 1988) gave evidence of substantial fragmentation of the European financial services markets since it found substantial price differentials. Price differentials were based on the percentage differences in prices of standard financial service products for each country compared with the average price for the four lowest-priced countries. In a second step, Cecchini estimated potential benefits arising for consumers from financial market integration, i.e. the gains in consumer surplus resulting from price reductions. The obvious problems with this kind of studies ${ }^{10}$ are the big difficulties to find completely homogeneous financial products

\footnotetext{
${ }^{9}$ Table 1 refers to this strand of literature as the "Antitrust-Literature".

${ }^{10}$ Gardener and Teppett (1995) replicate the microeconomic methodology of the Cecchini study and reveal other shortcomings.
} 
and the fact that absolute prices for not strictly homogeneous products are not comparable (Zimmerman, 1995).

Besides Cecchini, to our knowledge, only Centeno and Mello (1999), Kleimeier and Sander (2000) and Sander and Kleimeier (2001) focus on the European retail financial sector. All of them use cointegration techniques in order to measure financial market integration.

\subsection{The cointegration approach}

European retail financial markets are characterised by heterogeneity across countries that is caused by, for example, risk differences, cultural influences in bank-client relationship, country-specific strategic bank behaviour in order to cope with informational imperfections such as moral hazard or incentive effects (Sander and Kleimeier, 2001). Consequently, prices will not strictly equalise even in fully integrated markets. The law of one price, i.e. interest rate parity can hold solely for assets that are perfect substitutes across countries such as government bonds or money market instruments.

However, pricing in retail banking will be more closely tied together within an increasingly integrating region (Kleimeier and Sander, 2000). Thus, in integrated markets there should exist a certain long-run relationship between interest rates across countries. Certainly, this relationship does not require rates to equalise. And obviously, in the short-run retail rates will deviate from this long-run equilibrium but this existing long-run relationship limits divergence of rates in an integrated market. Therefore, the concept of cointegration can be employed to assess the degree of integration in retail financial markets. Cointegration means that there exists such a long-run relationship between two or more time series.

Centeno and Mello (1999) use cointegration techniques to test for financial market integration in six EU member states. They find money market rates to be closely linked across countries but the European bank loans market to be rather segmented.

Kleimeier and Sander (2000) also apply cointegration tests in order to assess the extent to which interest rate linkage in Europe might have become stronger over time. They apply the cointegration tests to lending rates, for what they choose the respective national prime rates, and to interest rate spreads, which they calculate by using the money market interest rate as a proxy for the deposit rate. They find prime rates and spreads not to be co-integrated for most of the European countries in the period between 1993 and 1997. This lack of cointegration could imply either that two markets are not linked at all or that convergence is under way since structural breaks in the standard cointegration tests can wrongly lead to the rejection of cointegration. Kleimeier and Sander (2000) infer an increase in the degree of financial market integration in the post-1993 period. 
Using data from the ECB's National Retail Interest Rate Statistics, Sander and Kleimeier (2001) (SK from here on) perform cointegration tests for three retail rates: the mortgage loan rate charged to households (N2), the consumer loans rate charged to households (N3), and the short-term lending rate charged to the corporate sector (N4). ${ }^{11}$ They find some tendencies for a more integrated corporate lending market, while consumer lending markets are still rather fragmented.

In this paper we choose a similar cointegration approach in order assess the degree of integration in the European retail financial market. We also use data from the ECB's National Retail Interest Rate Statistics but extend SK by an additional lending rate, namely the rate for medium and long-term loans to enterprises (N5) and two deposit rates, namely for time deposits (N8) and savings accounts (N9).

SK test for cointegration between the national retail rate and the average interest rate among the remaining Euroland countries. Using the average seems to be problematic because it imposes implicitly a severe restriction on the cointegration equation. Also, interpretation seems to be irritating: what exactly means cointegration between one country and the EU average? Hence, we test for cointegration between every possible pair of national retail rates. By doing so, we try to get some kind of pattern of countries that are integrated for every retail rate. Additionally to this bivariate approach, we conduct multivariate cointegration tests.

Usually, in the cases where cointegration is found a vector error correction model is estimated. SK do so in order to assess the degree of market integration. Such an error-correction specification allows to estimate how fast retail rates are driven back to their long-run equilibrium. SK argue that the faster the adjustment process, the stronger is integration of the national market (with the average of the rest of the countries) which allows primarily for a comparison of the degree of integration across countries within one market. However, it seems to be more interesting to draw comparisons concerning the degree of integration among the different European retail markets. In this paper we test for bivariate cointegration between every possible pair of countries and take the relative number of cointegration relationships found in a certain retail market as an indication for the degree of integration. An additional estimation of the error correction model would not give any further information concerning the degree of integration - it would not make sense to compare the degree of integration between two pairs of countries. Consequently, we do not estimate a vector error correction model and stop the analysis after having assessed integration by testing for bivariate and multivariate cointegration.

${ }^{11} \mathrm{~N} 2, \mathrm{~N} 3, \mathrm{~N} 4, \mathrm{~N} 5, \mathrm{~N} 8$ and N9 refer to the numbers of the series as reported by the ECB. 
Furthermore, compared to SK we use a somewhat different definition of integration underlying the cointegration approach. SK do not differentiate between integration that is due to the single European currency and integration that is due to factors such as deregulation or technical progress since they use interest rate levels and do not adjust for exchange rate fluctuations before the introduction of the Euro. We regard this approach as problematic since the result of increasing integration in this type of analysis could simply be caused by the end of exchange rate volatility. This finding, however, does not say much about integration of retail markets. In order to allow for more meaningful results we instead adjust for exchange rate related interest differentials by using spreads between the national retail rate and the national money market rate. In the case of long-term lending rates, i.e. the mortgage rate we subtract the bond yield. ${ }^{12}$ Hence, the cointegration equation can be written as

$$
S_{i t}=a+b S_{j t}+u_{t}
$$

where $S_{i t}$ and $S_{j t}$ is the spread between the retail rate and the money market rate (or the bond yield) of country $i$ and $j$ at time $t$, respectively. $u_{t}$ is an error term.

If cointegration between the interest rate spreads is found, this means that markets are tied together by a long-run relationship, i.e. markets are integrated. In the shortrun, however, deviations from this relationship can occur. Such deviations should be corrected over time by cross-border lending or increasing international competition (Sander and Kleimeier, 2001): When banks shift their lending activities to countries where lending rates are the highest and consumers or firms borrow in countries where rates are lowest, this international arbitrage process leads to a correction of deviations from the long-run equilibrium. Furthermore, increasing international competition - or as to the theory of contestable markets, the threat of it - lead to similar pricing behaviour of banks. With an already fully integrated European money market this should lead to a harmonisation of retail prices, since banks should pass changes in the underlying cost of funds onto consumers in the same way across countries. ${ }^{13}$

\footnotetext{
${ }^{12}$ These spreads can be interpreted as the bank margins. However, since the ECB statistic contains aggregated rates there may be differences in the term structure between lending rates and market rates that curtail this kind of interpretation. Consequently, spreads may also be negative over some periods - as figures $1 \mathrm{a}$ and $1 \mathrm{~b}$ beneath reveal.

${ }^{13}$ However, so far interest rate pass-through in Europe is still heterogeneous (Heinemann and Schüler, 2002).
} 


\section{Integration in the European retail financial market}

\subsection{The data}

As mentioned above we examine four lending rates and two deposit rates, that are taken from the ECB's National Retail Interest Rate Statistics. Namely this is interest rates for mortgage loans to households (N2), consumer loans to households (N3), short-term loans to enterprises (N4), medium and long-term loans to enterprises (N5), time deposits (N8), and savings accounts (N9). Unfortunately, a problem of the database is that interest rates are not harmonised. However, as mentioned above, using cointegration analysis takes somewhat care of this problem since rates are not expected to fully equalise even when markets are fully integrated.

A second problem results from the fact that the introduction of the Euro may have lead to a structural break in the cointegration relationship (e.g., Sander and Kleimeier, 2001). SK account for this structural break by dividing the data into a "pre-Euro period" and a "Euro period". However, cointegration analysis requires data over long periods of time. In addition, the time period for which data for all European countries is available simultaneously is limited. Therefore, we choose not to account for structural breaks explicitly. Possibly, using interest rate spreads instead of levels may weaken this disregard.

Another source for a structural break may have been the Second Banking Directive which was adopted in 1989, implemented on January 1, 1993 and completed formally the single European banking market. Also, by the beginning of 1993 in all EU countries consumer interest rates were completely deregulated (Guardia, 2000). In order to account for this potential structural change, we use monthly data beginning in January 1993. For this period for almost all countries data are available and even in the rare cases where series start in 1995 cointegration results are comparable. $^{14}$

In the following we use nominal rates because consumers and firms look at nominal rates when borrowing or investing money. Inflation in the foreign country, and thus, real interest rates do not matter to them.

Interest rate spreads are calculated by subtracting the long-term-government bond yield from the mortgage rate. For all other lending rates the 3-month-money market rate is used, as well as for the time and savings deposit rates. The bond yields and the money market rates are taken from the IMF's International Financial Statistics.

${ }^{14}$ All retail rates for Austria and the United Kingdom, as well as the mortgage rate and the time deposit rate for Italy are only available from 1995 on. For Germany the medium and long-term loans rate to enterprises starts in 1996. 
The study is conducted for Austria (AT), Belgium (BE), Finland (FI), France (FR), Germany (DE), Ireland (IE), Italy (IT), the Netherlands (NL), Portugal (PT), Spain (ES) and the United Kingdom (UK), although not all retail rates are available for every country.

The analysis proceeds as follows: Before testing for cointegration some descriptive statistics are presented. Then the spread series are tested for unit roots and in a first step we test for bivariate cointegration. Based on patterns obtained from this bivariate analysis, in a second step, multivariate cointegration tests are conducted.

\subsection{Stylised facts}

Before testing for cointegration some simple descriptive statistics are presented. Figure $1 \mathrm{a}$ and $1 \mathrm{~b}$ show exemplary the evolution of the interest rate levels and the spreads for mortgage loans to households. Clearly, a convergence of the mortgage interest rates has occurred. However, the convergence of spreads is not as obvious, indicating that the convergence in levels may be largely due to the removal of exchange rate risk. This confirms our proceeding of using interest rate spreads instead of levels when testing for cointegration, since before 1999 the relationship between interest rate levels is biased due to exchange rates fluctuations. Basically the same holds true for the other retail interest rates, although convergence is not that obvious for all rates.

Figure 1a: Interest rates for mortgage loans

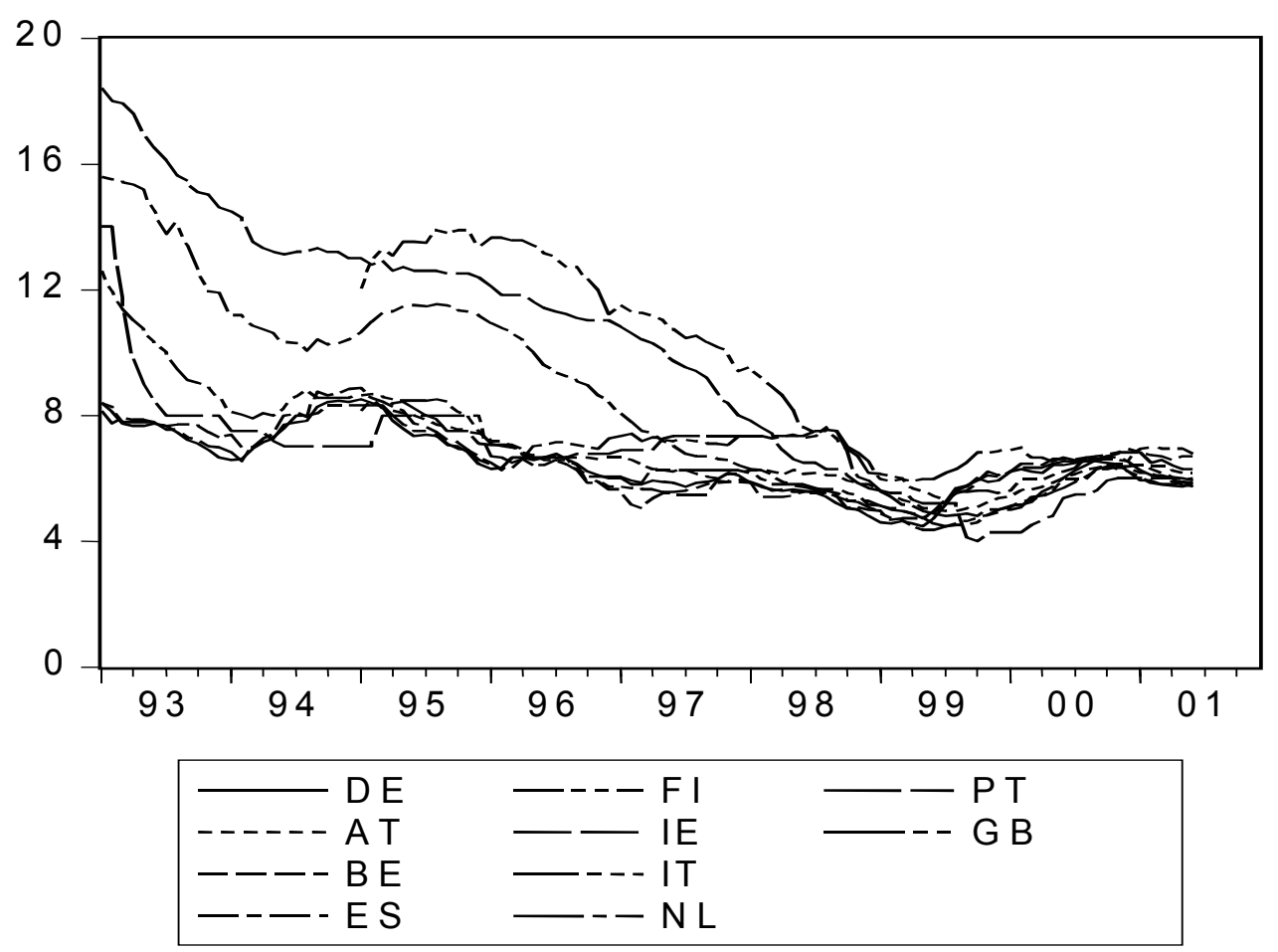


Figure 1b: Spreads between mortgage rate and the long-term-government bond yield

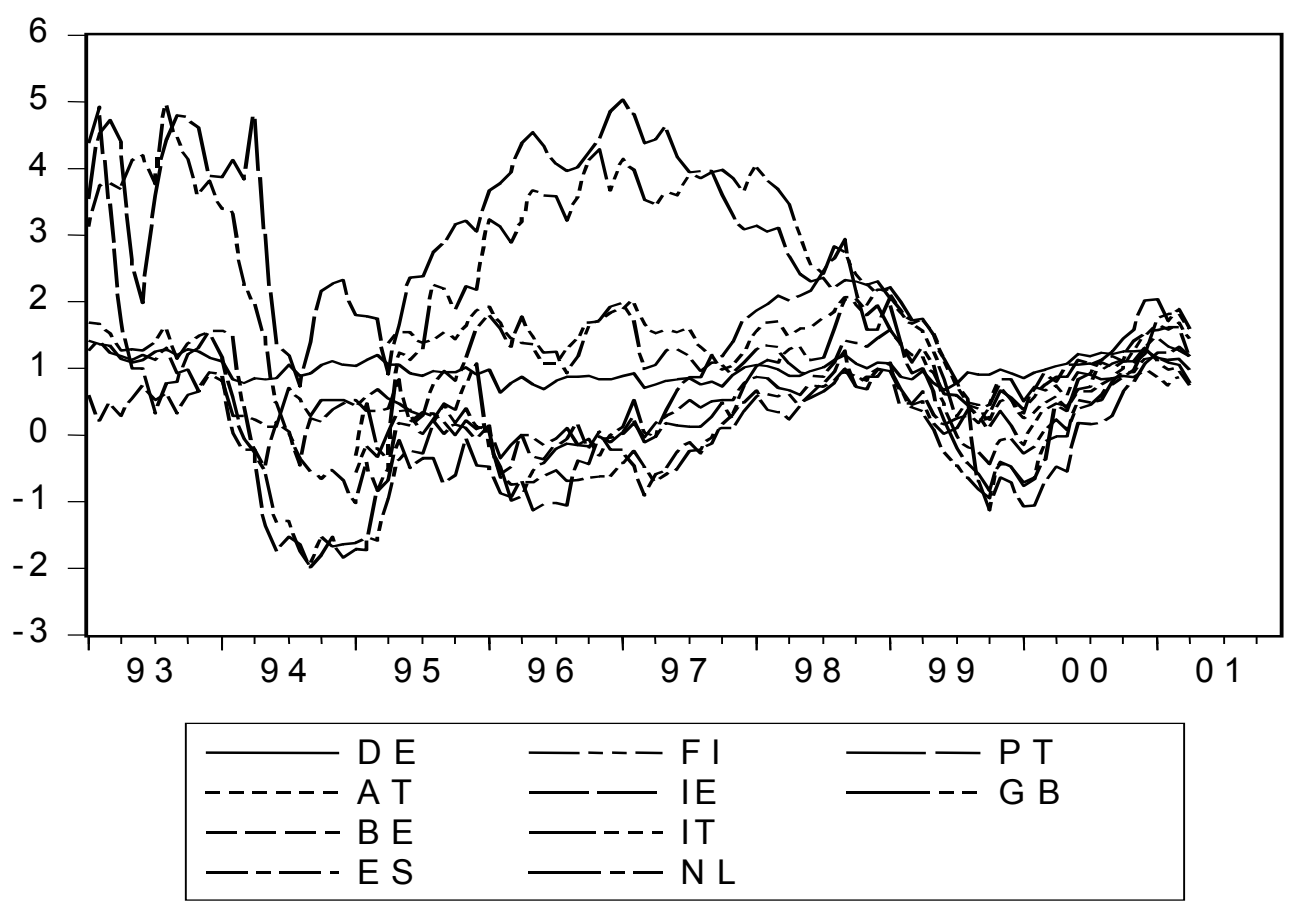

To get a first impression how strong interest rate spreads are linked correlation coefficients are calculated. Table 2 shows average correlations for the different countries for the six retail markets. The whole available sample period from January 1980 to Mai 2001 is divided into three sub-periods: the period before completion of the single banking market which was achieved by the Second Banking Directive in January 1993, the pre EMU period, and the EMU period. 
Table 2: Average correlation coefficients between national interest rate spreads

\begin{tabular}{ccccccccccccc}
\hline \hline Period & DE & AT & BE & ES & FR & FI & IE & IT & NL & PT & UK & Total \\
\hline & & \multicolumn{1}{c}{ Mortgage loans to households } \\
$1980-2001$ & 0.25 & 0.32 & 0.24 & 0.43 & N.A. & 0.54 & 0.43 & 0.14 & 0.25 & 0.20 & 0.34 & 0.31 \\
$1980-1992$ & 0.42 & N.A. & 0.49 & 0.24 & N.A. & N.A. & 0.40 & N.A. & 0.38 & 0.53 & N.A. & 0.41 \\
$1993-1999$ & 0.37 & 0.27 & 0.31 & 0.48 & N.A. & 0.57 & 0.52 & 0.10 & 0.43 & 0.07 & 0.43 & 0.35 \\
$1999-2001$ & 0.45 & 0.66 & 0.59 & 0.76 & N.A. & 0.79 & 0.59 & 0.72 & 0.54 & 0.79 & 0.58 & 0.65 \\
\hline
\end{tabular}

\section{Consumer loans to households}

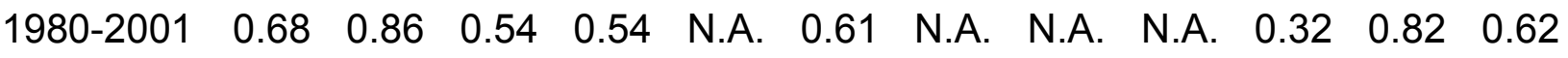
1980-1992 -0.18 N.A. N.A. -0.05 N.A. $0.10 \quad$ N.A. N.A. N.A. -0.39 N.A. -0.13

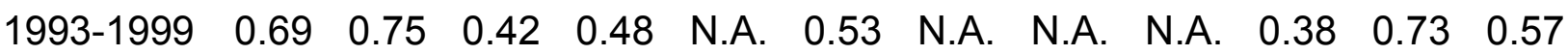
$\begin{array}{lllllllllllll}1999-2001 & 0.68 & 0.86 & 0.54 & 0.54 & \text { N.A. } & 0.61 & \text { N.A. } & \text { N.A. } & \text { N.A. } & 0.32 & 0.82 & 0.62\end{array}$

\section{Short-term loans to enterprises}

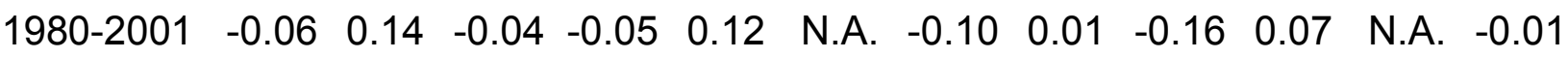
$\begin{array}{lllllllllllll}1980-1992 & -0.10 & \text { N.A. } & 0.11 & -0.08 & 0.15 & \text { N.A. } & -0.03 & 0.10 & -0.02 & 0.11 & \text { N.A. } & 0.03\end{array}$ $\begin{array}{lllllllllllll}1993-1999 & 0.09 & 0.19 & -0.01 & -0.03 & 0.17 & \text { N.A. } & 0.03 & -0.08 & -0.22 & 0.08 & \text { N.A. } 0.02\end{array}$

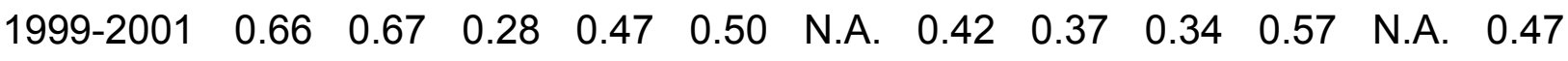

\section{Medium and long-term loans to enterprises}

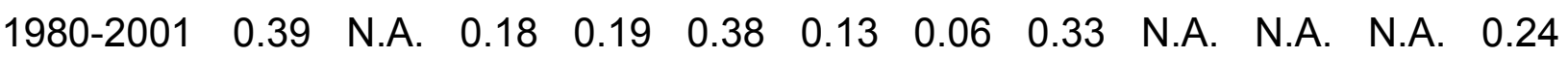
1980-1992 N.A. N.A. $0.00 \quad 0.21 \quad 0.23 \quad-0.12 \quad 0.36 \quad$ N.A. N.A. $\quad$ N.A. N.A. 0.14

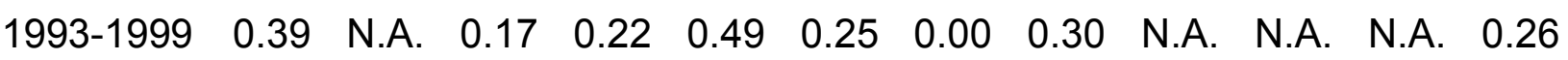

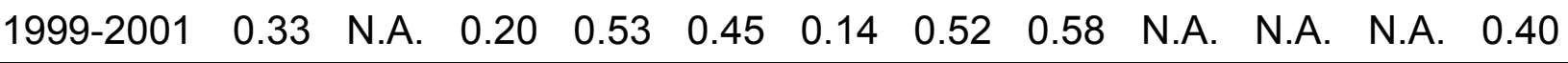

\section{Time deposits}

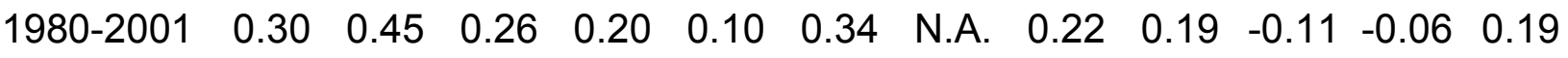

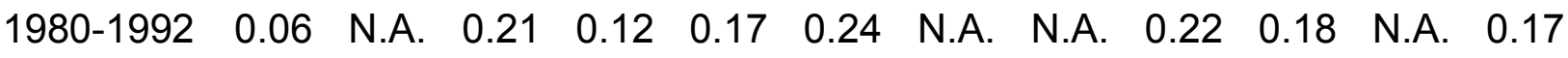
$\begin{array}{lllllllllllll}1993-1999 & 0.36 & 0.24 & 0.32 & 0.25 & 0.01 & 0.16 & \text { N.A. } & 0.30 & 0.27 & 0.22 & -0.33 & 0.18\end{array}$ $\begin{array}{lllllllllllll}1999-2001 & 0.76 & 0.77 & 0.77 & 0.67 & 0.25 & 0.72 & \text { N.A. } & 0.76 & 0.43 & 0.77 & 0.38 & 0.63\end{array}$

\section{Savings deposits}

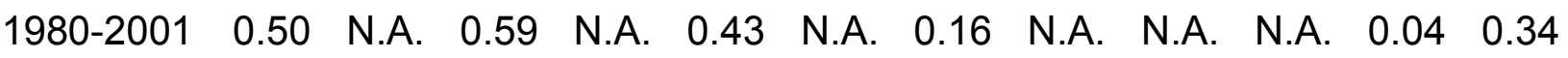
1980-1992 0.03 N.A. 0.12 N.A. $0.00 \quad$ N.A. $0.21 \quad$ N.A. N.A. N.A. N.A. 0.09

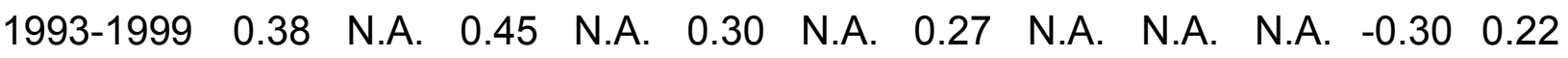

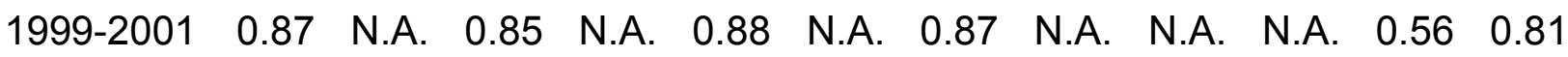

Average of bilateral correlation coefficients of a country's retail rate with all other countries' retail rates. 
Due to the lack of availability of data for a number of countries in the 1980's the coefficients for the period before the completion of a single banking market should not betaken too seriously. Comparing the coefficients for the periods before and after the introduction of the Euro shows that correlation for all countries has become stronger. In general, no consistent statement is possible concerning which market exhibits the higher correlations. Hence, table 2 does not reveal which market may be more integrated. In the next section tests for cointegration are conducted in order to assess the degree of integration.

\subsection{Testing for cointegration - the bivariate case}

Before testing for cointegration, tests for the existence of a unit root in the time series of interest rate spreads were conducted. In the following, all series of spreads are treated as I(1) processes. ${ }^{15}$ The results of the augmented Dickey-Fuller (ADF) and the Kwiatkowski, Phillips, Schmidt and Shin (KPSS) unit root tests are available upon request from the authors.

Cointegration is tested using the Johansen procedure. We use a model with an intercept in the cointegration equation but not in the vector autoregression part and with no deterministic trend as the data series exhibit such characteristics (first differences of the series fluctuate around zero). As for the lag structure in the model, an unrestricted vector autoregression model in first differences is estimated and the lag length is chosen according to the Akaike-criterion which makes sure that the residuals in each equation of the model are uncorrelated.

The results for the four lending rates and the two deposit rates are reported in tables $3 \mathrm{a}$ to $3 \mathrm{f}$. The tables display the lag length used for testing for bivariate cointegration and - according to the Trace statistic - if cointegration was found. One star indicates that cointegration was found at the $5 \%$ - two stars at the $1 \%$ significance level. More detailed results are available from the authors.

${ }^{15}$ Only in the following cases we had problems to reject the null hypothesis of stationarity: for the mortgage rate and the short-term business lending rate for Ireland, for the time deposit rate for Belgium, Spain and France. 
Table 3a: Results of bivariate cointegration tests: Existence of cointegration (optimal lag length in brackets): Mortgage loans to households (N2)

\begin{tabular}{|c|c|c|c|c|c|c|c|c|c|}
\hline & AT & $\mathrm{BE}$ & ES & $\mathrm{FI}$ & IE & IT & $\mathrm{NL}$ & PT & UK \\
\hline $\mathrm{DE}$ & no (2) & $\begin{array}{c}\text { yes }^{*} \\
(4)\end{array}$ & $\begin{array}{c}\text { yes }^{*} \\
(3)\end{array}$ & no (3) & no (5) & no (1) & $\begin{array}{c}\text { yes }^{* *} \\
(1)\end{array}$ & no $(7)$ & no $(5$ \\
\hline AT & & no (2) & no (1) & no (1) & no (1) & no (1) & no (1) & no (1) & no ( \\
\hline$B E$ & & & $\begin{array}{c}\text { yes }^{*} \\
(10)\end{array}$ & no (3) & no (5) & no (1) & $\begin{array}{c}y^{\text {yes* }} \text { (1) } \\
\text { (1) }\end{array}$ & $\begin{array}{c}\text { yes* }^{*} \\
(8)\end{array}$ & no $(3$ \\
\hline ES & & & & no (1) & no $(10)$ & no (9) & no (4) & no (4) & no $(4$ \\
\hline $\mathrm{FI}$ & & & & & no (1) & no (1) & $\begin{array}{l}\text { yes* }^{*} \\
\text { (3) }\end{array}$ & no (4) & no ( \\
\hline $\mathrm{IE}$ & & & & & & no (1) & no $(6)$ & no $(10)$ & no ( \\
\hline IT & & & & & & & no (1) & no (1) & no ( \\
\hline $\mathrm{NL}$ & & & & & & & & no (7) & no ( \\
\hline PT & & & & & & & & & no ( \\
\hline $\begin{array}{l}* * * * \quad T \\
\text { sign }\end{array}$ & $\begin{array}{l}\text { ce stati } \\
\text { cance }\end{array}$ & tistic of $\mathrm{JC}$ & hansen & test in & licates $c$ & ointegrat & with & $5 \% / 1 \%$ & evel \\
\hline \multicolumn{10}{|c|}{ Table 3b: Consumer loans to households (N3) } \\
\hline & & AT & $\mathrm{BE}$ & & $S$ & $\mathrm{FI}$ & PT & \multicolumn{2}{|l|}{ UK } \\
\hline & $\mathrm{DE}$ & yes $^{* *}(10)$ & no (1) & & (2) & no (3) & no (4) & \multicolumn{2}{|c|}{ no (1) } \\
\hline & AT & & no (4) & & (1) & no (1) & no (1) & \multicolumn{2}{|c|}{ no (1) } \\
\hline & $\mathrm{BE}$ & & & & (2) & no (5) & no (1) & \multicolumn{2}{|c|}{ no (1) } \\
\hline & $E S$ & & & & & $10(10)$ & no (5) & \multicolumn{2}{|c|}{ no (1) } \\
\hline & $\mathrm{FI}$ & & & & & & no (9) & \multicolumn{2}{|c|}{ no (5) } \\
\hline & $\mathrm{PT}$ & & & & & & & \multicolumn{2}{|c|}{ no (3) } \\
\hline
\end{tabular}


Table 3c: Short-term loans to enterprises (N4)

\begin{tabular}{|c|c|c|c|c|c|c|c|c|}
\hline & AT & $\mathrm{BE}$ & ES & FR & IE & IT & $\mathrm{NL}$ & PT \\
\hline $\mathrm{DE}$ & no (1) & $\operatorname{yes}^{*}(1)$ & $\operatorname{yes}^{*}(1)$ & no $(7)$ & $\begin{array}{c}\text { yes }^{* *} \\
(8)\end{array}$ & no (1) & no (1) & no $(7)$ \\
\hline AT & & no (1) & no (5) & no (3) & no (1) & no (1) & no (1) & no (2) \\
\hline$B E$ & & & no (5) & no (10) & $\begin{array}{c}\text { no } \\
(10)^{16}\end{array}$ & $\begin{array}{l}\text { yes* } \\
\text { (10) }\end{array}$ & no (1) & no (10) \\
\hline ES & & & & no (7) & $\begin{array}{c}\text { yes }^{* *} \\
(8)\end{array}$ & no (4) & no (1) & no (8) \\
\hline FR & & & & & $\begin{array}{l}\text { yes }^{*} \\
(10)\end{array}$ & $\operatorname{yes}^{*}(9)$ & no (7) & no (9) \\
\hline $\mathrm{IE}$ & & & & & & $\begin{array}{c}\text { yes }^{* *} \\
(5)\end{array}$ & $\begin{array}{c}\text { yes }^{* *} \\
(5)\end{array}$ & $\begin{array}{c}\text { yes }^{* *} \\
(10)\end{array}$ \\
\hline IT & & & & & & & no (1) & $\begin{array}{c}\text { yes }^{* *} \\
(10)\end{array}$ \\
\hline $\mathrm{NL}$ & & & & & & & & no (7) \\
\hline
\end{tabular}

Table 3d: Medium and long-term loans to enterprises (N5)

\begin{tabular}{|c|c|c|c|c|c|c|}
\hline & $\mathrm{BE}$ & ES & FR & $\mathrm{FI}$ & $\mathrm{IE}$ & IT \\
\hline $\mathrm{DE}$ & no (1) & yes $^{* *}(6)$ & yes $^{* *}(1)$ & no (2) & no (1) & $\operatorname{yes}^{* *}(1)$ \\
\hline $\mathrm{BE}$ & & $\operatorname{yes}^{* *}(10)$ & no (9) & no (5) & yes $^{*}(9)$ & no (1) \\
\hline ES & & & no (10) & no $(10)$ & $\operatorname{yes}^{* *}(10)$ & $\operatorname{yes}^{*}(1)$ \\
\hline FR & & & & no (10) & $\operatorname{yes}^{* *}(10)$ & no (5) \\
\hline $\mathrm{FI}$ & & & & & yes $^{*}(9)$ & yes $^{*}(2)$ \\
\hline $\mathrm{IE}$ & & & & & & no (1) \\
\hline
\end{tabular}

${ }^{16}$ In this case two cointegration equations were found. When two cointegration equations are found in the bivariate case this indicates that the series are stationary. Indeed, we had problems to reject stationarity for Ireland whereas the Belgium series clearly is I(1). 
Table 3e: Time deposits (N8)

\begin{tabular}{|c|c|c|c|c|c|c|c|c|c|}
\hline & AT & $\mathrm{BE}$ & ES & $\mathrm{FI}$ & $\mathrm{FR}$ & $\mathrm{NL}$ & IT & PT2 & UK \\
\hline $\mathrm{DE}$ & no (3) & $\begin{array}{c}y^{*} s^{* *} \\
(3)\end{array}$ & $\begin{array}{c}\text { yes }^{* *} \\
(10)\end{array}$ & no (5) & $\begin{array}{c}y^{*} s^{* *} \\
(9)\end{array}$ & no (2) & no (1) & $\begin{array}{c}y^{*} s^{* *} \\
(7)\end{array}$ & no (2) \\
\hline AT & & no (1) & no (4) & no (2) & $\begin{array}{c}y^{* s^{* *}} \\
(2)\end{array}$ & no (1) & no (1) & no (2) & no (1) \\
\hline $\mathrm{BE}$ & & & $\begin{array}{c}\text { yes }^{* *} \\
(10)\end{array}$ & $\begin{array}{c}\text { yes }^{* *} \\
(10)\end{array}$ & $\begin{array}{c}\text { yes }^{* *} \\
(7)\end{array}$ & $\begin{array}{c}\text { yes }^{* *} \\
(3)\end{array}$ & no (2) & $\begin{array}{c}\text { yes }^{* *} \\
(8)\end{array}$ & no (1) \\
\hline ES & & & & $\begin{array}{l}\text { yes }^{*} \\
(10)\end{array}$ & $\begin{array}{c}\text { yes }^{* *} \\
(10)\end{array}$ & $\begin{array}{c}\text { yes }^{* *} \\
(10)\end{array}$ & $\begin{array}{c}y^{*} s^{* *} \\
(2)\end{array}$ & $\begin{array}{c}\text { yes }^{* *} \\
(10)\end{array}$ & no (2) \\
\hline $\mathrm{FI}$ & & & & & $\begin{array}{c}y^{*} s^{* *} \\
(7)\end{array}$ & no (4) & no (2) & no (9) & no (1) \\
\hline FR & & & & & & $\begin{array}{c}\text { yes }^{* *} \\
(9)\end{array}$ & $\begin{array}{c}\text { yes }^{* *} \\
(3)\end{array}$ & $\begin{array}{c}\text { yes }^{* *} \\
(10)\end{array}$ & $\begin{array}{c}y^{*} s^{* *} \\
(3)\end{array}$ \\
\hline $\mathrm{NL}$ & & & & & & & no (1) & no (8) & no (1) \\
\hline IT & & & & & & & & $\begin{array}{c}y^{*}{ }^{* *} \\
(1)\end{array}$ & $\begin{array}{c}y^{*} s^{*} \\
(2)\end{array}$ \\
\hline PT2 & & & & & & & & & no (1) \\
\hline
\end{tabular}

Table 3f: Savings accounts (N9)

\begin{tabular}{ccccc}
\hline & BE & FR & IE & UK \\
\hline $\mathrm{DE}$ & no (10) & $\operatorname{yes}^{* *}(3)$ & no (6) & no (1) \\
\hline BE & & $\operatorname{yes}^{* *}(10)$ & no (9) & no (1) \\
\hline FR & & & $\operatorname{yes}^{*}(10)$ & no (1) \\
\hline IE & & & & no (1) \\
\hline
\end{tabular}

Clearly, there are differences across the different markets. Looking at the relative numbers of cointegration relationships found, there is some evidence for integration in the market for short-term as well as for medium and long-term loans to enterprises, and also in the time deposits market. In the markets for mortgage loans and consumer loans to households as well as in the market for savings deposits only a few cointegration relationships are found, giving some indication that those markets are rather fragmented.

Looking in closer detail, in the market for mortgage loans to households in only 7 out of 21 possible combinations cointegration was found. Only the spreads for mortgage loans between Germany and the Netherlands, and the spreads between Belgium and the Netherlands were co-integrated at the 1\% significant level. All in all there were 4 cointegration relationships found for Belgium, 3 for Germany and the Netherlands, 2 for Spain, and 1 for Finland and Portugal. No cointegration was found for Austria, Ireland, Italy and the United Kingdom. These numbers indicate that so far there exists no single European mortgage loans market although there is 
some evidence for integration in Belgium, Germany, the Netherlands and maybe Spain. Figure 2 illustrates this pattern. The lines indicate that a bivariate cointegration relationship was found between the two countries, respectively.

Figure 2: Cointegration relationships in the mortgage market

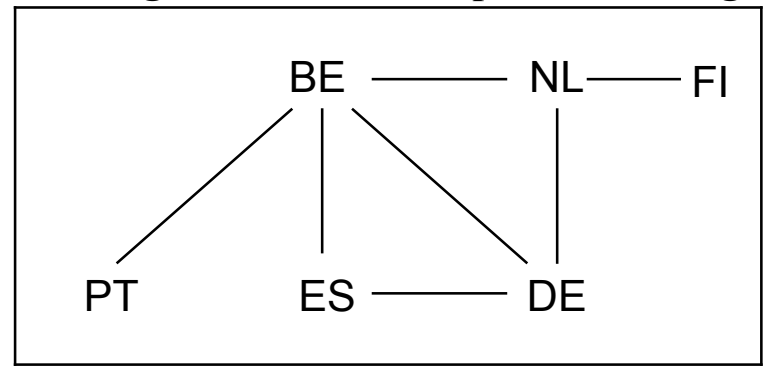

In the consumer loans market only 1 cointegration relationship was found, indicating that only the markets of Germany and Austria are integrated. This gives some evidence that there exist substantial obstacles to the integration of the European markets for consumer loans to households.

Hence, whereas the market for consumer loans does not show any sign of integration for the mortgage loans market there is at least some evidence for integration although there exists no single European mortgage market. This result seems to be plausible since in the mortgage market, for example, monitoring is a smaller problem than in the consumer loans market where also personal bank-customerrelationships probably play a major role.

More integrated seems to be the market for short-term loans to enterprises. In 11 out of 36 possible combinations cointegration was found. For Ireland 6 cointegration relationships were found, 4 for Italy, 3 for Germany, 2 for Belgium, Spain, France and Portugal, and 1 for the Netherlands. Only in the case of Austria no cointegration was found. Figure 3 a illustrates the bivariate cointegration relationships in the case of short-term loans to enterprises. It seems that Ireland builds something like a centre that links a number of other national markets. However, we had problems with the rejection of stationarity for the spread series for Ireland which may be a explanation for the high numbers of cointegration relationships found for Ireland. When dropping Ireland from the sample in 5 out of 28 possible combinations bivariate cointegration is found. Figure $3 b$ illustrates this case which reveals some evidence for integration among Italy, Portugal, France, Belgium, Germany and Spain. 
Figure 3a: Cointegration relationships in the market short-term loans to enterprises

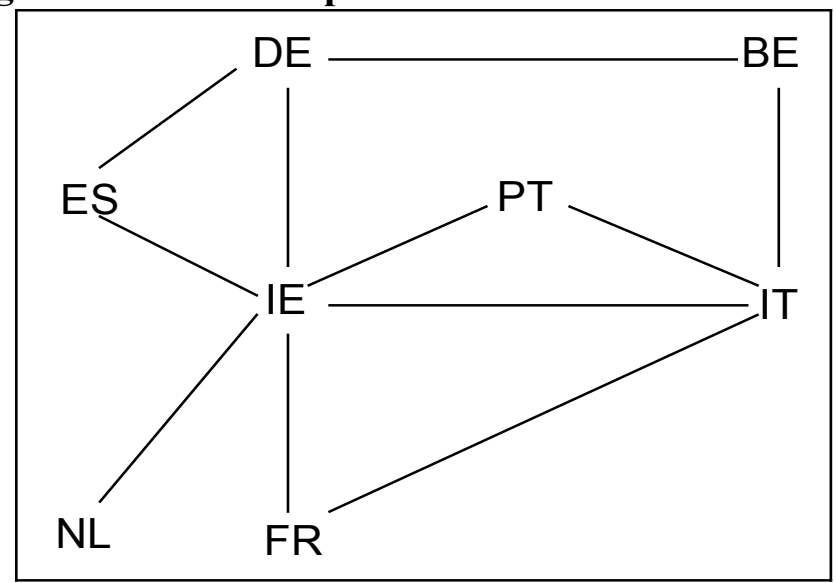

Figure 3b: Cointegration relationships in the market short-term loans to enterprises when Ireland is dropped from the sample

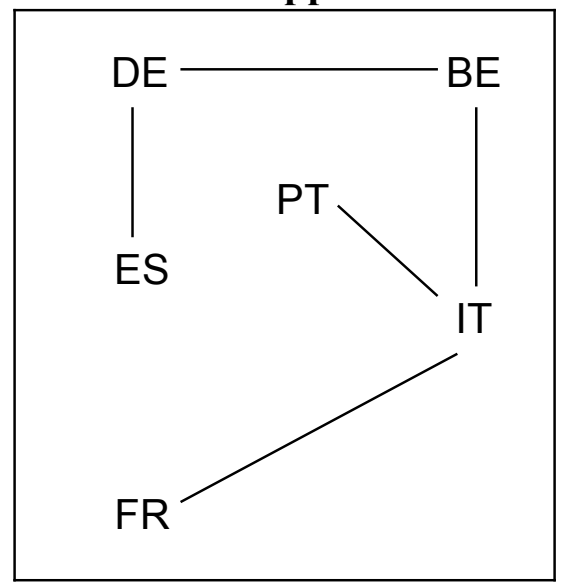

Also we get evidence that the European market for medium and long-term loans to enterprises is to some extent integrated since we found in almost every second case cointegration (10 out of 21). We found 4 cointegration relationships for Spain and Ireland, 3 for Germany and Italy, and 2 for Belgium, France and Finland. Figure 4 illustrates the bivariate cointegration relationships in the case of medium and longterm loans to enterprises. 


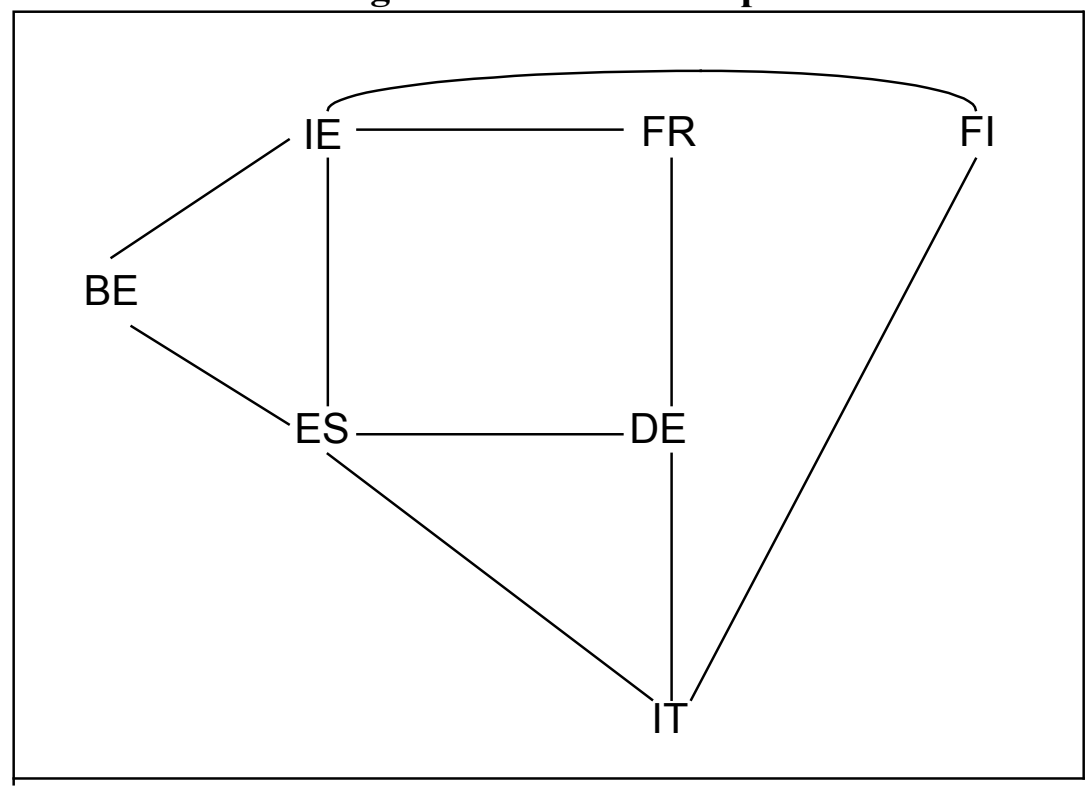

In general, enterprises may borrow money from a bank abroad rather than consumers. Thus, cross-border competition in the markets for loans to enterprises probably is higher than in the markets for mortgage or consumer loans. This puts more pressure on banks in the enterprise loans market to pass a decrease in their cost of funds, i.e. the money market rate to the lenders. In this way financial market integration is fostered and this explains our findings of lower integration in the mortgage and consumer loans market than in the loans markets for enterprises. ${ }^{17}$

In the time deposits market in 22 out of 45 possible combinations cointegration was found giving some evidence that the market is integrated to a large extent. This seems to be plausible since traditionally time deposits are strongly linked to the money market. With the introduction of a single currency a single European money market emerged which in the case of time deposits may have enforced integration. In addition, compared to, for example, savings deposits time deposits are predominantly made by wealthier or even institutional investors that may rather invest in a foreign country than a "normal saver". Thus, also higher cross-border competition may foster market integration. However, in this case we had problems to reject stationarity for some spread series, namely for Belgium, Spain and France. Clearly, this limits interpretation.

${ }^{17}$ Our finding that the firms loans market is more integrated than the households loans market is basically in line with Sander and Kleimeier (2001). However, they found evidence that the consumer loans market is somewhat more integrated than the market for mortgage loans market. 
There seems to be little evidence for integration in the European savings deposit market since we found only in 3 cases cointegration. It looks like France is integrated with Germany, Belgium and Ireland whereas no other cointegration relationships were found. A possible explanation for this lack of integration in the savings deposits market may be that savings deposits are usually made by savers that attach much importance to a personal customer-bank-relationship. Hence, crossborder competition is probably relatively low hindering integration in this market. Unfortunately, the number of countries for which interest rate data on savings deposits is available is small compared with the other markets so that comparisons have to be interpreted with caution.

To summarise, we find evidence that integration in the markets for mortgage and consumer loans to households is relatively low. The markets for short-term as well as medium and long-term loans to enterprises seem to be integrated at least to some extent. Concerning deposits, our results indicate that the time deposit market is to quite an amount integrated whereas the markets for savings deposits are rather fragmented.

\subsection{The multivariate case}

Based on the patterns obtained from the bivariate case (see figures 2 to 4 ) we test for multivariate cointegration. The bivariate case ignores that there may exist integration of two markets through a third market, i.e. there may exist a long-run, cointegration relationship that ties several markets together whereas such a relationship is not found between two markets alone (Harris, 1995). So we look for samples of countries that exhibit one - and only one - cointegration equation. All countries in such a sample are tied to this one cointegration equation in the long-run which gives evidence for financial integration of these countries. When taking cointegration as evidence for market integration more than one cointegration equation economically does not make sense (Kremer, 1999). Therefore, when a sample of countries exhibits more than one cointegration equation we search for other samples that exactly have one cointegration equation.

Again, cointegration is tested using the Johansen procedure and prior the lag length is chosen according to the Akaike criterion from a unrestricted vector autoregression model in first differences. The detailed test results can be obtained upon request.

In the market for mortgage loans to households the sample of countries including Germany, Belgium, the Netherlands, and Spain exhibits exactly one cointegration equation. This confirms our findings from the bivariate cointegration tests illustrated in figure 2. Although there exists no single European mortgage market there is some evidence that markets in Germany, Belgium, the Netherlands, and Spain are to some extent integrated. 
In regard to the consumer loans market our finding from the bivariate case that there are no signs for integration are also confirmed in the multivariate case. The sample with all countries for which data is available reveals no cointegration. The same holds true when the United Kingdom as a non-Euroland country is dropped from the sample as well as for any other multivariate combination of countries.

For the medium and long-term loans to enterprises we find one cointegration equation for the sample including Spain, Germany, Italy, Ireland and Belgium. Looking at figure 4 reveals that this finding confirms to some amount the results of the bivariate analysis. However, taking France and/or Finland into the sample one gets more than one cointegration relationships. This points to an integrated "core" of countries, namely Spain, Germany, Italy, Ireland and Belgium to which France and Finland have some link.

Concerning the savings deposits market we find one cointegration equation for the sample of all Euroland countries for which data is available, i.e. Germany, Belgium, France and Ireland indicating market integration for these countries. However, this evidence is rather weak since the trace statistic allows only for a rejection of the null of no cointegration relationship at the 5\% level and the max-eigenvalue test even indicates no cointegration among these countries. As mentioned above, bearing in mind that only for five countries data is available this result has to be interpreted with care anyway.

In regard to the European time deposits market we tested a number of possible combinations of countries for multivariate cointegration. We found for the sample including Germany, Belgium, Spain, France and Italy one cointegration equation. These countries were together with Portugal the countries for which the most bivariat cointegration relationships were found. Taking Portugal into the sample we found more than one cointegration equation. These findings indicate that there exists a "core" including the biggest European economies that have integrated markets for time deposits and that countries like Portugal, the Netherlands, Finland and Austria are linked through bivariat relationships to this "core". All in all the findings from the multivariate analysis - like the ones from the bivariate analysis - can be taken as evidence that the European time deposit market is to quite an amount integrated.

For the market for short-term lending to enterprise the results of the multivariate analysis are not presented as neither the results of the bivariate analysis are confirmed nor other reasonable patterns are obtained. 


\section{Obstacles to integration in retail financial markets}

The analyses in the previous section give some evidence that although there are some signs for integration so far a single European retail financial market does not exist. This holds true especially for the loans markets to consumers, i.e. the mortgage and the consumer loans market, and for the savings deposit market. But also the loans market to enterprises seems to be not fully integrated. Thus, the question emerges of what are the reasons for this lack of integration, i.e. what are the obstacles to retail financial market integration.

In general, fragmentation in markets for financial services can either be due to policy-induced or to natural factors. Policy-induced obstacles are regulation and taxes, in particular, obstacles that can be reduced by policy-makers. As opposed to this, natural obstacles are independent of political actions at least in the short and medium-run. Such barriers to financial market integration are, for example, preferences and confidence of consumers, differences in culture and/or language, and distance.

SK cite Tommaso Padoa-Schioppa with the words "proximity is an intrinsic characteristic of the retail market with or without the emergence of a currency embracing a wider area" (Sander and Kleimeier, 2001, p 1). In regard to loans to consumers the previous analyses somewhat confirm this assessment. In the mortgage market only between Germany and the Netherlands, and between Belgium and the Netherlands cointegration was found at a $1 \%$ significant level. In the consumer loans market only Germany and Austria were co-integrated. The closer links between neighbouring and common language countries indicate that for those markets distance and maybe also language may constitute natural obstacles to integration. However, this assessment is not confirmed for the other retail markets since there cointegration is found also for countries that are far away from each other. And even, when taking not just cointegration at the $1 \%$-level distance seems to play no major role in the mortgage market.

In general, factors like distance, the presence of a common language, and a common legal system influence the information costs associated with bank lending. The presence of information costs hinders direct cross-border bank lending which means lower financial market integration (Buch, 2000). In particular, this should be essential for financial services that are not standardised and where monitoring plays a major role like with consumer loans or small business lending. Market segmentation that results from information costs can hardly be reduced by policy actions.

In addition to these natural obstacles to market integration there are policy induced obstacles -regulations in particular. Buch (2000) finds evidence that the EU's Single 
Market program and the Basle Capital Accord have had a positive impact on crossborder banking activity. On the other side, factors like the still high cost for crossborder transfers and lack of consumer protection may impair consumers in opening an account for time or savings deposits at a foreign bank. This includes issues such as cross-border redress and price transparency. Such obstacles should be addressed by policy makers and, to some extent, policy action has been taken or is underway. ${ }^{18}$

The revolution in information technology and in particular the internet is often said to overcome borders and in the context of financial retail markets to foster integration. Due to the technical advances, consumers are no longer bound to national or regional firms, they are able to shop around at all companies worldwide that provide services online. As a consequence, information costs are reduced and cross-border competition is enhanced which fosters financial market integration. However, due to factors like the preference of consumers for domestic suppliers overcoming fragmentation in retail financial markets remains hard to achieve (Schüler, 2002).

In summary, the cointegration analyses in the previous sections allows only for limited statements concerning the obstacles to integration of the European retail financial markets. For the loans markets to consumers there is some evidence that distance matters whereas for the loans markets to enterprises and the deposit markets this assessment is not confirmed. This seems to be quite plausible - firms rather than households may look for a cheaper credit at a foreign bank.

\section{Conclusion}

With the introduction of a single European currency a fully integrated European money market emerged and also other wholesale financial markets are generally regarded as highly integrated. In spite of this single wholesale financial market European retail financial markets still reveal substantial fragmentation. We analysed four lending markets and two deposit markets by testing for cointegration between national interest rate spreads. Comparing the markets in particular, we find evidence that the markets for loans to households are less integrated than the enterprise loans markets. In regard to lending to households we found more integration for mortgages than for consumer credit where almost no signs for integration were found at all. This may be explained by lower information costs for the mortgage credit since it is secured by real estate. We found evidence that the European time deposit market is to quite an amount integrated which is probably due to the fact that

${ }^{18}$ For a more detailed description of the policy action that has been taken to strengthen consumer protection in cross-border financial business see Schüler (2002). 
time deposits are traditionally strongly linked to the money market. For the savings deposit market the analyses showed a relatively low degree of integration.

Of course, the analyses in this paper can give just some evidence to the question of financial market integration since there remain problems with the data and also with the cointegration approach. For example, in periods of convergence cointegration tests may misleadingly reject cointegration (Kleimeier and Sander, 2000). However, as section 2 has shown measuring financial market integration has been a difficult task - particularly for retail financial markets where the availability of useful data is strongly limited.

All in all the analyses have shown that retail financial markets seem to be far from being truly integrated. Thus, there is potential for further integration in retail financial markets. Clearly, a single European market for financial services would improve households and firms financing possibility. However, considering the underlying obstacles to integration that are at least to some extent natural, eventually in the short and medium-run, national retail financial markets will remain segmented to a certain degree.

\section{References}

Ayuso, J. and R. Blanco (2000), Has Financial Market Integration Increased During the 1990s?, BIS Conference Papers No.8, Basle.

Bayoumi, T. (1990), Saving-Investment Correlations: Immobile Capital, Government Policy, or Endogenous Behavior? IMF Staff Papers Vol. 37 (2), 360-387.

Bayoumi, T. and R. MacDonald (1995), Consumption, Income, and International Capital Market Integration, IMF Staff Papers Vol. 42 (3), 552-576.

Beckaert, G. and C. R. Harvey (1995), Time-Varying World Market Integration, Journal of Finance Vol. 50 (2), 403-444.

Berger, A. N. and T. H. Hannan (1998), The Price-Concentration Relationship in Banking, The Review of Economics and Statistics Vol. 71 (2), 291-299.

Buch, C. (2000), Information or Regulation: What is Driving the International Activities of Commercial Banks?, Kiel Working Paper No. 1011, Kiel. 
Chen, Z. and P. J. Knez (1995), Measurement of Market Integration and Arbitrage, Review of Financial Studies Vol. 8 (2), 287-325.

Centeno, M. and A. S. Mello (1999), How integrated are the money market and the bank loans market within the European Union?, Journal of International Money and Finance 18, 75-106.

Commission of the European Communities (1988), European economy: The economies of 1992, no 35, March, Brussels: Commission of the European Communities.

Dumas, B. and B. Solnik (1995), The World Price of Foreign Exchange Risk, Journal of Finance Vol. 50 (2), 445-479.

Guardia, N. D. (2000), Consumer Credit in the European Union, European Credit Research Institute, ECRI Research Report No.1, Brussels.

Eijffinger, S. C. W. and J. J. G. Lemmen (1995), Money Market Integration in Europe, Swiss Journal of Economics and Statistics Vol. 131 (1), 3-37.

Feldstein, M. and C. Horioka (1980), Domestic Saving and International Capital Flows, The Economic Journal 90, 314-329.

Feldstein, M. (1982), Domestic Saving and International Capital Movements in the Long Run and the Short Run, NBER Working Paper No. 947, Cambridge.

Ferson, W. E. and C. R. Harvey (1991), The Variation of Economic Risk Premiums, The Journal of Political Economy Vol. 99 (2), 385-415.

Frankel, J. A. (1992), Measuring International Capital Mobility: A Review, The American Economic Review Vol. 82 (2), 197-202.

Frankel, J. A. (1993), Quantifying International Capital Mobility in the 1980s, in: Bernheim, D. (Ed.), National Saving and Economic Performance, Chicago, 227-260.

Fratzscher, M. (2001), Financial Market Integration in Europe: On the Effects of EMU on Stock Markets, ECB Working Paper No. 48, Frankfurt.

Gardener, E. P.M. and J. L. Teppett (1995), A Select Replication of the Cecchini Microeconomic Methodology on the EFTA Financial Services Sectors: A Note and Critique, The Service Industries Journal 15, 74-89.

Goldstein, M. and M. Mussa (1993), The Integration of World Capital Markets, IMF Working Paper WP/93/95, Washington.

Hannan, T. H. (1991), Bank Commercial Loan Markets and the Role of Market Structure: Evidence from Surveys of Commercial Lending, Journal of Banking and Finance 15, 133-149.

Hannan, T. H. and A. N. Berger (1991), The Rigidity of Prices: Evidence from the Banking Industry, The American Economic Review Vol. 81 (4), 938-945. 
Hardouvelis, G., D. Malliaropulos and R. Priestley (1999), EMU and European Stock Market Integration, CEPR Discussion Paper No. 2124, London.

Harris, R. (1995), Using Cointegraion Analysis in Econometric Modelling, London.

Heinemann, F. and M. Schüler (2002), Interest Rate Pass-Through and Imperfect Integration of EU Markets for Financial Services, mimeo.

Heinemann, F. and C. Stirböck (1999), Capital Mobility within EMU, ZEW Discussion Paper No. 99-19, Mannheim.

Heitfield, E. A. (1999), What Do Interest Rate Data Say About the Geography of Retail Banking Markets?, The Antitrust Bulletin (Summer), 333-347.

Hess, G. D. and K. Shin (2000), Risk Sharing by Households Within and Across Regions and Industries, Journal of Monetary Economics 45, 533-560.

International Monetary Fund (2000), Annual Report on Exchange Arrangements and Exchange Restrictions 2000, Washington.

Jackson III, W. E. (1992), Is the Market Well Defined in Bank Merger and Acquisition Analysis?, The Review of Economics and Statistics Vol. 74 (4), 665-661.

Keeley, M. C. and G. C. Zimmerman (1985), Determining Geographic Markets for Deposit Competition in Banking, Economic Review - Federal Reserve Bank of San Francisco, 25-45.

Kellermann, K. und C.-H. Schlag (1999), Eine Untersuchung der ErsparnisInvestitions-Korrelation in Deutschland, Zeitschrift für Wirtschafts- und Sozialwissenschaften (ZWS) 119, 99-119.

Kleimeier, S. and H. Sander (2000), Regionalisation versus globalisation in European financial market integration: Evidence from cointegration analyses, Journal of Banking and Finance 24, 1005-1043.

Kremer, M. (1999), Die Kapitalmarktzinsen in Deutschland und den USA: Wie eng is der Zinsverbund? Eine Anwendung der multivariaten Kointegratinsanalyse, Diskussionspapier 2/99, Volkswirtschaftliche Forschungsgruppe der Deutschen Bundesbank.

Lapp, S. (1996), The Feldstein-Horioka Paradox: A Selective Survey of the Literature, Kiel Working Paper No. 752, Kiel.

Lemmen, J. J. G. and S. C. W. Eijffinger (1993), The Degree of Financial Integration in the European Community, De Economist 141 (2), 189-213.

Lemmen, J. J. G. and S. C. W. Eijffinger (1995), Financial Integration in Europe: Evidence from Euler Equation Tests, Working Paper, Tilburg University, Tilburg.

Lewis, K. K. (1999), Trying to Explain Home Bias in Equities and Consumption, Journal of Economic Literature Vol. 37, 571-608. 
Mace, B. J. (1991), Full Insurance in the Presence of Aggregate Uncertainty, The Journal of Political Economy Vol. 99 (5), 928-956.

Murphy, R. G. (1984), Capital Mobility and the Relationship Between Saving and Investment Rates in OECD Countries, Journal of International Money and Finance (3), 327-342.

Neumark, D. and S. A. Sharpe (1992), Market Structure and the Nature of Price Rigidity: Evidence from the Market for Consumer Deposits, Quarterly Journal of Economics Vol. 107 (2), 657-680.

Obstfeld, M. (1985), Capital Mobility in the World Economy: Theory and Measurement, NBER Working Paper No. 1692, Cambridge.

Obstfeld, M. (1989), How Integrated Are World Capital Markets? Some New Tests, in: Calvo, G., R. Findlay, P. Kouri and J. Braga de Macedo (Eds.), Debt, Stabilization and Development, Oxford, 134-155.

Obstfeld, M. (1994), Are Industrial-Country Consumption Risks Globally Diversified?, in: Leiderman, L. and A. Razin, Capital Mobility: The Impact on Consumption, Investment and Growth, Cambridge, 13-44.

Obstfeld, M. (1995), International Capital Mobility in the 1990s, in: Kenen, P. K., Understanding Interdependence: The Macroeconomics of the Open Economy, Princeton, 201-261.

Olivei, G. P. (2000), Consumption Risk-Sharing Across G-7 Countries, New England Economic Review (March/April), 3-14.

Radecki, L. J. (1998), The Expanding Geographic Reach of Retail Banking Markets, FRBNY Economic Policy Review (June), 15-34.

Radecki, L. J. (1999), Bank Restructuring and Financial Stability in the United States, BIS Conference Papers Vol. 7, Basle, 319-340.

Rhoades, S. A. (1992), Evidence on the Size of Banking Markets from Mortgage Loan Rates in Twenty Cities, Board of Governors of the Federal Reserve System Staff Studies No. 162, Washington.

Schulze, G. G. and H. W. Ursprung (1999), Globalisation of the Economy and the Nation State, The World Economy 22, 295-352.

Sander, H. and S. Kleimeier (2001), Towards a Single Retail Banking Market? New Evidence from Euroland, forthcoming in: Australasian Journal of European Integration.

Schüler, M. (2002), Integration of the European Market for E-Finance - Evidence from Online Brokerage, mimeo.

Sinn, S. (1992), Saving-Investment Correlations and Capital Mobility: On the Evidence from Annual Data, The Economic Journal 102, 1162-1170. 
Summers, L. H. (1988), Tax Policy and International Competitiveness, in: Frenkel, J. (Ed.), International Aspects of Fiscal Policies, Chicago, 349-386.

Stigler, G. J. and R. A. Sherwin (1985), The Extent of the Market, Journal of Law \& Economics Vol. 28, 555-585.

Taylor, A. M. (1994), Domestic Saving and International Capital Flows Reconsidered, NBER Working Paper No. 4892, Cambridge.

Taylor, A. M. (1996), International Capital Mobility in History: The SavingInvestment Relationship, NBER Working Paper 5743, Cambridge.

Tesar, L. L. and I. M. Werner (1992), Home Bias and the Globalization of Securities Markets, NBER Working Paper No. 4218, Cambridge.

Tobin, J. (1983), Comments 'Domestic Saving and International Capital Movements in the Long Run and the Short Run' by M. Feldstein, European Economic Review 21, 153-156.

Zimmermann, G. C. (1995), Implementing the Single Banking Market in Europe, Federaö Reserve Bank of San Francisco Economic Review, No. 3, 35-51. 